\title{
The importance of reestablishing orbitary architecture for rehabilitation with an ocular prosthesis: a case report
}

\author{
A importância do restabelecimento da arquitetura orbitária para reabilitação com prótese ocular: \\ relato de caso
}

La importancia de restablecer la arquitectura orbitaria para la rehabilitación con prótesis ocular: reporte de un caso

Received: 12/26/2020 | Reviewed: 12/27/2020 | Accept: 12/30/2020 | Published: 04/01/2021

Eduardo Dallazen

ORCID: https://orcid.org/0000-0002-7994-5634 São Paulo State University “Julio de Mesquita Filho", Brazil E-mail: dallazen.d@gmail.com

Mariana Elias Queiroz ORCID: https://orcid.org/0000-0002-1036-2617 São Paulo State University "Julio de Mesquita Filho", Brazil E-mail: mariana.equeiroz@gmail.com Ângelo Rosso Llantada ORCID: https://orcid.org/0000-0003-3541-867X State University of Londrina, Brazil E-mail: angelobuco@hotmail.com

Marcelo Medeiros Battistetti ORCID: https://orcid.org/0000-0003-4742-0064 State University of Londrina, Brazil E-mail: mmbattistetti@gmail.com

Christopher Henrique Gibim ORCID: https://orcid.org/0000-0001-9063-1129 State University of Londrina, Brazil E-mail: gibim_00@hotmail.com

Eduardo Hochuli-Vieira ORCID: https://orcid.org/0000-0003-4040-9313 São Paulo State University “Julio de Mesquita Filho", Brazil E-mail: eduardo.hochuli@unesp.br Glaykon Alex Vitti Stabile ORCID: https://orcid.org/0000-0001-5878-9575 State University of Londrina, Brazil E-mail: glaykon.bmf@gmail.com

\begin{abstract}
Anophthalmia is mainly caused by two etiological groups, trauma and medical conditions. In addition, anophthalmia creates difficulties in social, professional, and family adaptation due to psychological, and functional disorders related to eye loss. Studies show a positive influence on the personal relationship of patients with anophthalmia after being rehabilitated with ocular prostheses. However, in order to achieve a good aesthetic result in prosthetic eye rehabilitation, it is essential that the size and positioning of the orbital skeleton are adequate. Facial trauma can also cause defects associated with bone loss, and in these cases, reconstructive techniques aim to restore the appropriate bone contour. The aim of this work is to report a case where reconstructive treatment was performed on a patient victim of a long-term traffic accident sequel, using an alloplastic implant in polymethylmethacrylate (PMMA) and bone repositioning, so that an ocular prosthesis could be made. At the end of the treatment, after reconstruction of the frontal-nasal region in PMMA and repositioning of the left zygoma, the aesthetic objectives were achieved and the patient improved his self-esteem and social life.
\end{abstract}

Keywords: Anophtalmos; Eye artificial; Polymethyl methacrylate.

\section{Resumo}

A anoftalmia é causada principalmente por dois grupos etiológicos, trauma e condições médicas. Além disso, a anoftalmia gera dificuldades na adaptação social, profissional e familiar devido aos transtornos psíquicos e funcionais relacionados a perda ocular. Estudos demonstram influência positiva no relacionamento pessoal dos pacientes com anoftalmia após serem reabilitados com próteses oculares. No entanto, para que seja alcançado um bom resultado 
estético na reabilitação protética ocular é essencial que o tamanho e posicionamento do esqueleto orbitário estejam adequados. O trauma facial também pode ocasionar defeitos associados a perda óssea, sendo que nestes casos, técnicas reconstrutivas objetivam devolver o contorno ósseo apropriado. O objetivo deste trabalho é relatar um caso onde foi realizado tratamento reconstrutivo de um paciente vítima de sequela de acidente de trânsito de longa data, por meio da utilização de implante aloplástico em polimetilmetacrilato (PMMA) e reposicionamento ósseo, para que fosse confeccionada uma prótese ocular. Ao final do tratamento, após a reconstrução da região fronto-nasal em PMMA e reposicionamento do zigoma esquerdo, os objetivos estéticos foram alcançados e o paciente obteve melhora da autoestima e do convívio social.

Palavras-chave: Anoftalmia; Olho artificial; Polimetil metacrilato.

\section{Resumen}

La anoftalmia es causada principalmente por dos grupos etiológicos, traumatismos y afecciones médicas. Además, la anoftalmia genera dificultades en la adaptación social, profesional y familiar debido a los trastornos psicológicos y funcionales relacionados con la pérdida de la vista. Los estudios muestran una influencia positiva en la relación personal de los pacientes con anoftalmia tras ser rehabilitados con prótesis oculares. Sin embargo, para lograr un buen resultado estético en la rehabilitación del ojo protésico, es fundamental que el tamaño y la posición del esqueleto orbitario sean los adecuados. El trauma facial también puede causar defectos asociados con la pérdida ósea y, en estos casos, las técnicas reconstructivas tienen como objetivo restaurar el contorno óseo adecuado. El objetivo de este trabajo es reportar un caso en el que se realizó un tratamiento reconstructivo a un paciente víctima de secuelas de accidente de tránsito de larga duración, utilizando un implante aloplástico en polimetilmetacrilato (PMMA) y reposicionamiento óseo, para que se pudiera realizar una prótesis ocular. Al final del tratamiento, tras la reconstrucción de la región fronto-nasal en PMMA y el reposicionamiento del cigoma izquierdo, se lograron los objetivos estéticos y el paciente mejoró su autoestima y vida social.

Palabras clave: Anoftalmos; Ojo artificial; Polimetil metacrilato.

\section{Introduction}

Anophthalmia is mainly associated with two etiological groups, trauma and medical conditions. Tumors, glaucoma, retinal detachment and diabetes are the main medical conditions for ocular loss, while occupational, sports, home and motor vehicle accidents represent the main traumatic etiologies. Estimates assume that there are approximately 145,000 users of ocular prostheses in Brazil (Pine et al., 2015).

Patients with anophthalmia may have difficulties in social, professional and family adaptation due to psychological and functional disorders related to eye loss. Sadness, shame, shyness, fear and concern to hide the affected eye are feelings frequently reported by patients with anophthalmia (Cabral et al., 2008; Goiato et al., 2013). Studies demonstrate that ocular prostheses have a positive influence on the personal relationship of patients with anophthalmia. Such patients report having overcome depression due to aesthetic improvement resulting from the use of an ocular prosthesis (Goiato et al., 2013).

For a good aesthetic result to be achieved in prosthetic eye rehabilitation, it is essential that the size and positioning of the orbital skeleton are adequate, such factors may be compromised in patients who are victims of facial trauma. The position and volume of the orbit depend directly on the bones that comprise it: frontal, lacrimal, ethmoid, zygomatic, maxillary, palatal and sphenoid. Fractures that affect such bones, when not treated or treated improperly, in addition to functional damage, can cause changes in the position of the eyeball and aesthetic deformities. (Starch-Jensen et al., 2018) The sequelae associated with fractures in the middle and upper thirds of the face may require osteotomies, refractures and placement of grafts and alloplastic implants (Gasparini et al., 2010; Gomes-Ferreira et al., 2015; Rodrigues et al., 2020).

Facial trauma can also cause defects associated with bone loss, and in these cases, reconstructive techniques aim to restore the appropriate bone contour. To perform the reconstruction of these defects, autogenous grafts and / or alloplastic materials can be used, such as titanium meshes, polyether ketone (PEEK), high density polyethylene (HDPE) and polymethylmethacrylate (PMMA). (Ghosh et al., 2017; Oliver et al., 2019) Discovered in 1930 by chemists Rowlland Hill and John Crawford and first applied by Otto Rohm in 1934, PMMA is a synthetic polymer of the methyl methacrylate monomer. 
First used in the second world war in aircraft and submarine parts, it was used for the first time in the field of health in the manufacture of dental prostheses. With high impact resistance, light, inert and with favorable and low-cost processing, PMMA represents the most popular material used in cranial reconstructions (Oliver et al, 2019; Ali et al., 2015; Rodríguez et al., 2007).

This work aims to report the reconstructive treatment of a patient who has suffered from a long-term traffic accident, in which demand was the installation of an eye prosthesis aiming at the aesthetic restoration and improvement of social life.

\section{Methodology}

This article is about a report of a clinical case, which aims to describe a clinical situation of a patient with sequelae from trauma and all stages of his treatment. For this reason, it was not submitted to the ethics committee, since the procedures performed on the patient are not experimental. A free and informed consent form was signed by the patient related to the procedures performed and the use of the images.

\section{Case Report}

Male patient, 62 years old, victim of a traffic accident for 20 years, which resulted in changes in the middle and upper third region of the face on the left side. Current imaging studies suggest Le Fort II type fractures, fractures of the right and left zygomatic-orbital complex, this with significant displacement, fracture of the nasal framework and frontal fracture with significant loss of anterior and posterior walls establishing communication between the cranial cavity and orbit. In addition, due to irreversible damage to the left eye, it was eviscerated. Changes in the left CZO led to a significant increase in the left orbital volume, unevenness between the orbital cavities and loss of the malar projection (Fig 4A and 4B).

The patient was referred by the Ophthalmology team to the Buco-Maxillofacial Surgery and Traumatology specialty for bone reconstruction of the affected areas due to the patient's aesthetic complaint and the impossibility of making the ocular prosthesis in the presented condition.

The tomographic examination made it possible to visualize the extent of bone defects in the anterior wall of the left frontal sinus, loss of continuity in the posterior wall of the frontal sinus and the altered positioning of the left CZO. Due to the clinical condition and magnitude of the necessary movements, considering the adhesion of dura mater to adjacent tissues, the treatment plan defined for the patient was aimed not at the replacement of all ill-positioned bone structures and inherent bone reconstructions, but at improvement of aesthetics and favorable conditions for prosthetic eye rehabilitation. From the printing of a study biomodel for teaching purposes and with the aid of the Erickson platform, measurements at anatomical points in the CZO region of the prototyped model were performed to guide the repositioning of the left zygoma in the model, based on the measurements on the right side. (Fig 1A, 1B, 1C) After repositioning the left zygoma, manual modeling and customization of the reconstruction of the frontal region with condensation silicone were carried out (Fig. 1D) (Profile Putty, Vigodent SA Industria e Comércio, Rio de Janeiro-Rio de Janeiro, BR). The modeled silicone served as a standard for an alloplastic implant in self-curing PMMA (JET Artigos Odontológicos Clássico Ltda, São Paulo-São Paulo, BR). The implant was acrilized in a dental muffle previously to the surgery and kept in a $2 \%$ aqueous chlorhexidine solution (Riohex, Rioquímica S / A Indústria, São José do Rio Preto-São Paulo, BR) until the time of surgery (Fig 3A). The planning of the repositioning of the left CZO in a digital environment was also carried out (Materialize Software, Leuven-Brabant Flamengo, BE), where a mirroring of the right zygoma served as a guide for the repositioning of the left zygoma, allowing the visualization of the movements to be performed in the surgery, and obtaining conference measures (Fig. 2A, 2B, 2C, 2D). 
Figure 1 - (A) (B) Examples of the reference measurements taken in the stereolithographic model in the right CZO region for repositioning the left CZO. (C) Left CZO repositioned according to reference measurements. (D) Manual modeling of frontal reconstruction with condensation silicone.
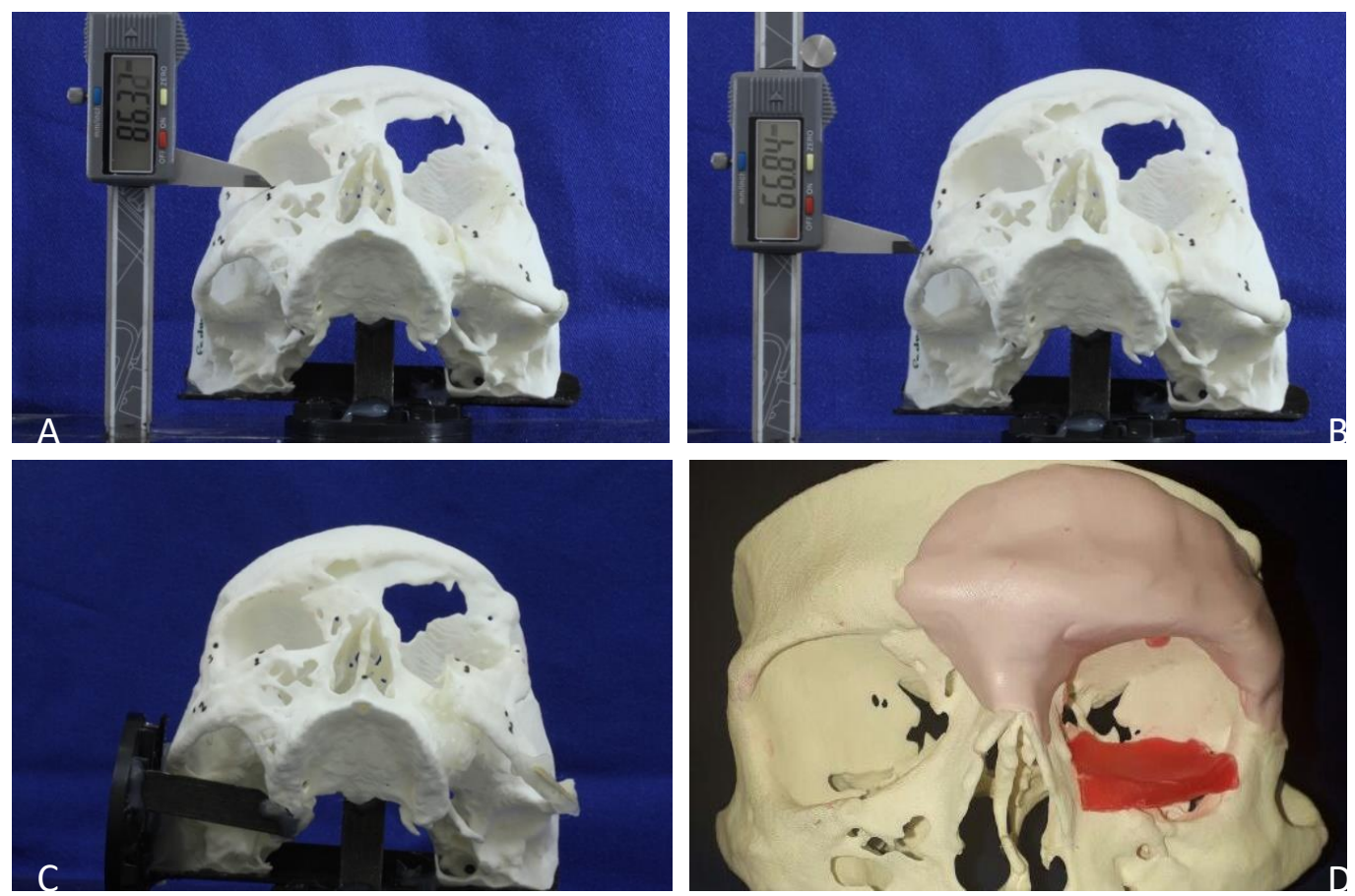

Source: Authors.

Figure 2 - (A) Mirroring the right CZO in digital software. (B) Repositioning of the left CZO with reference to the mirroring of the right $\mathrm{CZO}$. (C) Front view of the right $\mathrm{CZO}$ repositioned on the displaced bone structures. (D) Measurement of the distance between the repositioned $\mathrm{CZO}$ and the remaining structures.
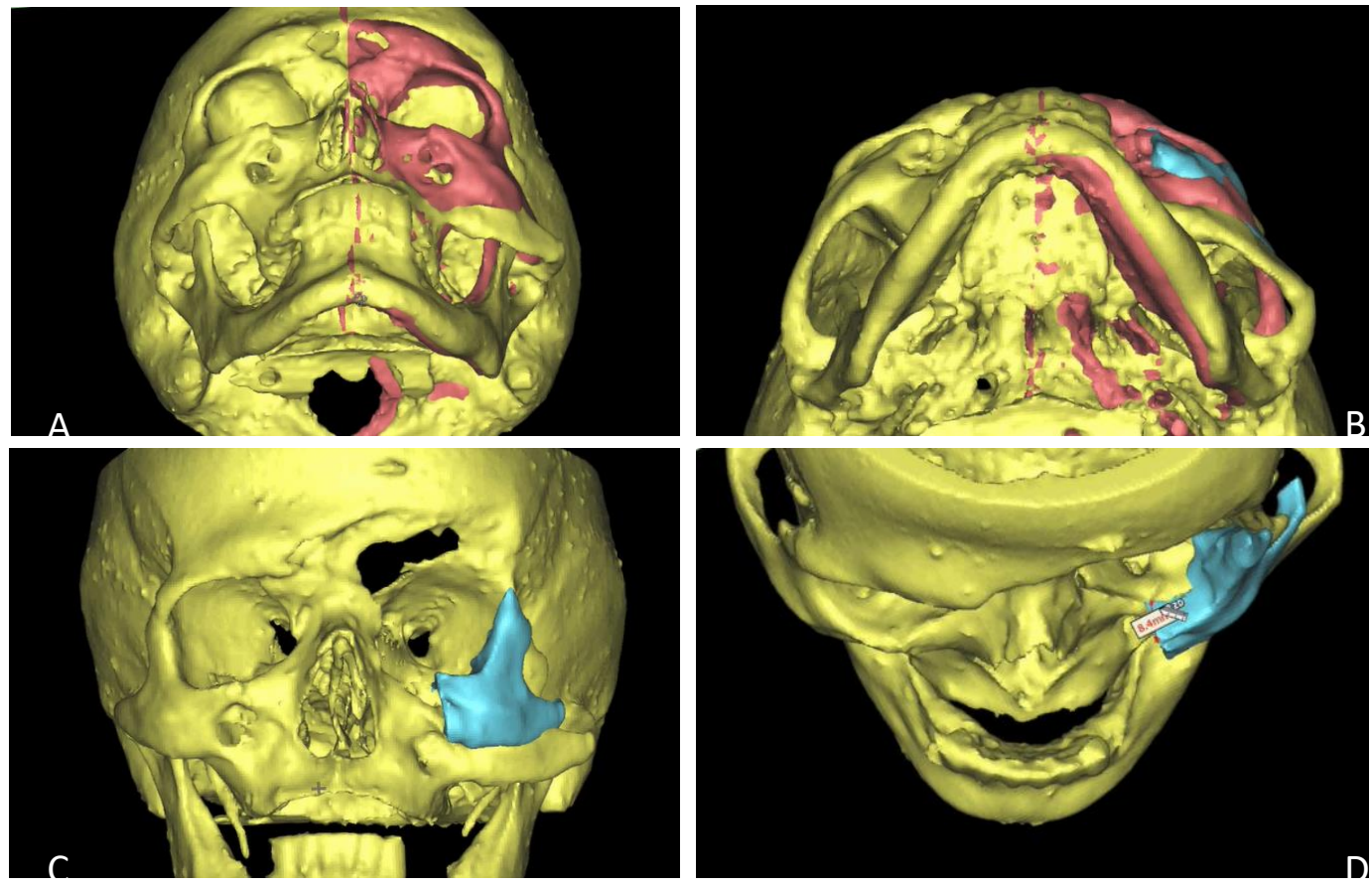

Source: Authors. 
The patient underwent a surgical procedure under general anesthesia, where bicoronal and left subciliary approaches were performed. After exposure of the defect in the frontal, nasal and misplaced CZO regions, the implant in PMMA was fixed in the frontal region with cortical screws of the $1.5 \mathrm{~mm}$ system. There was no need to repair the dura mater. Then, osteotomy was performed with a reciprocating saw from the fronto-zygomatic suture region, lateral orbit wall, zygomatic arch, zygomatic-maxillary suture and left orbital floor. Then, the left zygoma was repositioned, using the PMMA implant already fixed as the upper reference and the measurements performed in the digital software and in the Erickson platform as previous reference. The left CZO was fixed with mini plates and cortical screws of the $1.5 \mathrm{~mm}$ system. In the areas of unevenness bone in the infraorbital margin, grafting was performed with autogenous bone, removed from the skullcap, which was fixed with mini plates and cortical screws of the same fixation system. The floor was reconstituted with a $0.3 \mathrm{~mm}$ thick titanium mesh and autogenous graft from the skullcap, which were also fixed with $1.5 \mathrm{~mm}$ system cortical screws. Additionally, a skullcap graft was performed in the left malar region, seeking better projection of this region, which was fixed with a cortical screw too (Fig. 3B, 3C, 3D). Finally, the bicoronal flap was repositioned and sutured using plans for all accesses.

Figure 3 - (A) Alloplastic implant in PMMA. (B) Osteotomies for removal of autogenous bone graft from the skullcap. (C) Trans-surgical aspect of implant fixation in PMMA and CZO repositioned with graft in the left malar region. (D) Transsurgical aspect of the reconstruction of the orbital floor with titanium mesh and infraorbital rim with autogenous graft.
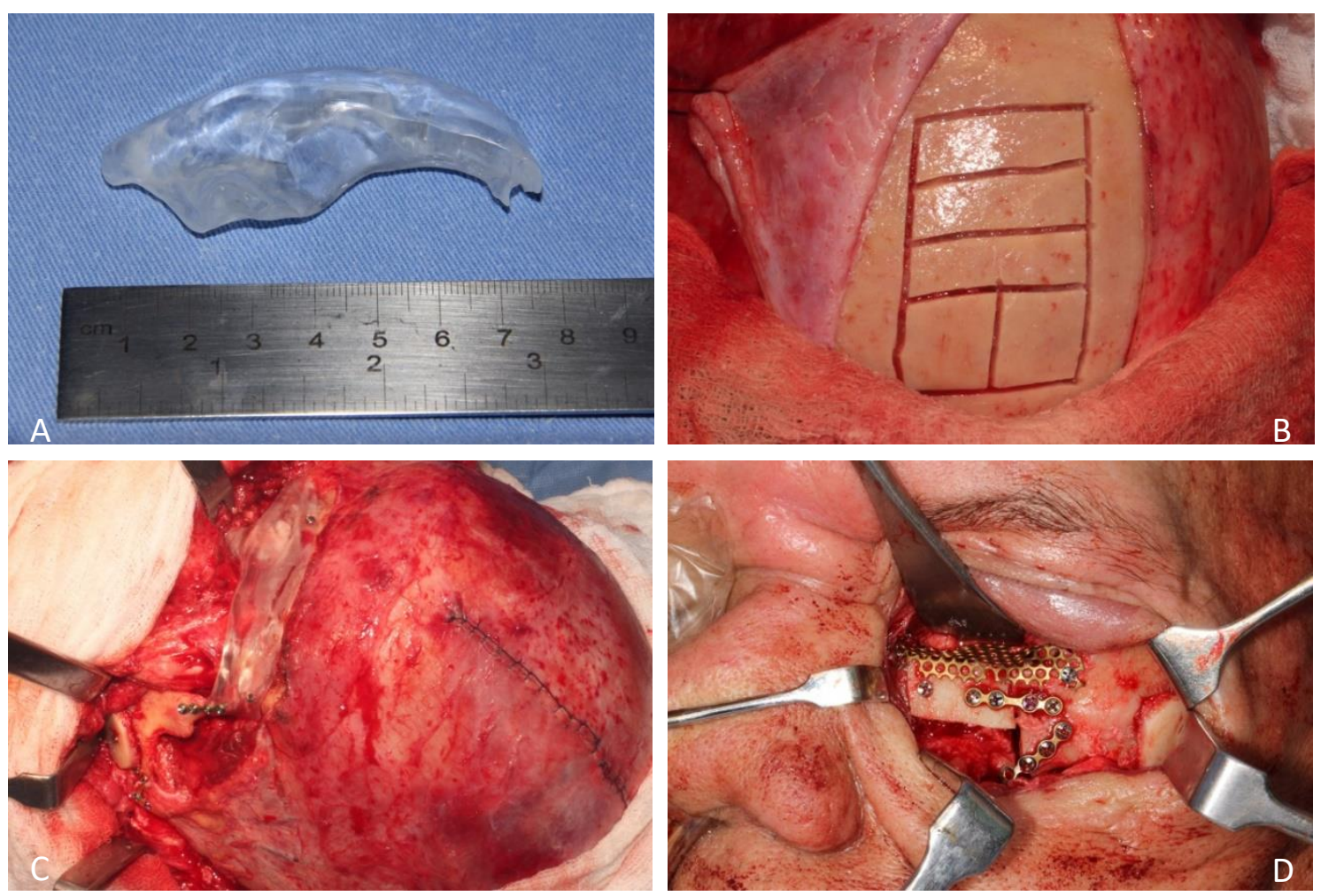

Source: Authors.

24 hours after the surgical procedure, the patient was discharged from the hospital. Orally Amoxicillin 500mg of 8/8 hours for 7 days, non-steroidal anti-inflammatory and analgesic were prescribed. The patient was followed up weekly for six weeks, showing good recovery, with good healing of surgical wounds, without infectious or inflammatory signs. There was no exposure of the PMMA implant, the eyelid commissures showed better leveling and improvement in frontal, zygomatic and nasal dorsal projection. 
A provisional ocular prosthesis was made in order to allow a better adaptation to its use. For this, the orbital cavity was molded with dental alginate (Hydrogun 5, Zhermack SpA, Badia Polesine-Rovigo, IT) and a model of the orbital cavity in type IV plaster was obtained (Durone, Dentsply, Petrópolis-Rio de Janeiro, BR). On the resulting model, an eye prosthesis was made in PMMA and iris printed from a photograph of the right eye. The provisional prosthesis was delivered 60 days after the operation and the patient was followed up (Fig. 4C, 4D). Due to the COVID-19 pandemic, the patient found it difficult to perform the definitive eye rehabilitation. One year after surgery, the patient received the definitive prosthesis after seeking assistance in a private service (Fig 4E, 4F). The patient was instructed on how to use and care for the new prosthesis and is followed up annually by the team. The same states that the reconstructive surgery and the realization of the ocular prosthesis made possible the significant improvement of self-esteem and social life.

Figure 4 - (A) Preoperative photograph in lateral view. (B) Pre-operative photograph in frontal view. (C) Post-operative photograph in lateral view with the provisional prosthesis. (D) Post-operative photograph in frontal view with the provisional prosthesis. (E) Post-operative photograph in lateral view with the definitive prosthesis. (F) Post-operative photograph in frontal view with the definitive prosthesis.
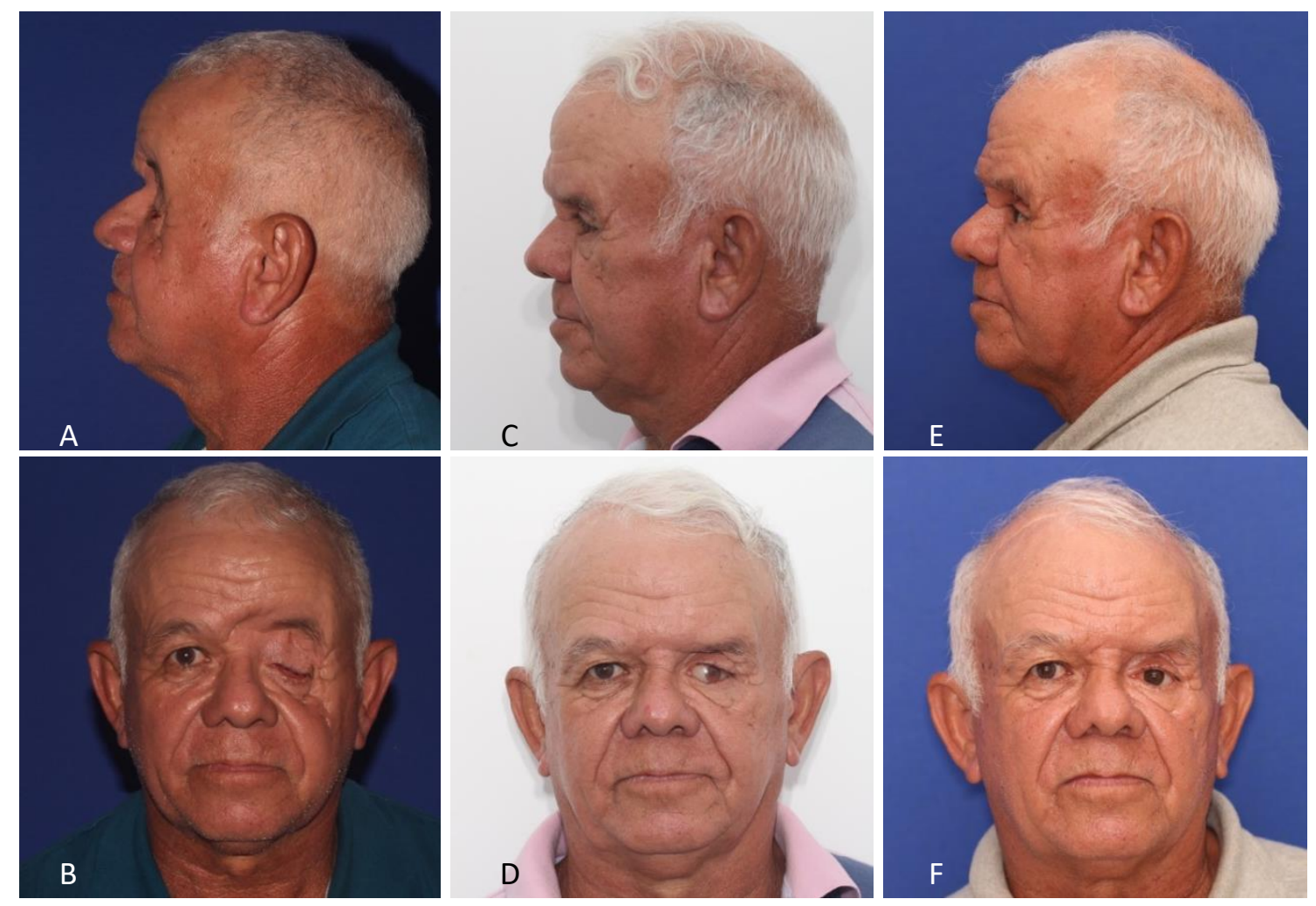

Source: Authors.

\section{Discussion}

In the context of prosthetic eye adaptation, facial dimensions and proportions are very important aspects that must be considered, since the eyes are among the main aesthetic elements that determine symmetry and facial expressions (Pine et al., 2015). In this sense, for the rehabilitation of the patient with anophthalmia, the maintenance of the structures responsible for the accommodation and placement of the ocular prosthesis is as important as its aesthetics. 
The orbit consists of seven bones that articulate and form a pyramid with four walls, with the base located in the anterior region and the apex in the posterior region (Colombo et al., 2011). The location of the prosthesis is determined by the integrity of the orbital cavity walls. Injuries caused to these structures can cause displacement and change in the shape of the soft tissues of the orbit, leading to alteration of the orbital volume and inadequate positioning of the ocular prosthesis (Batista; et al., 2020; Colombo et al., 2011). In the case reported, the patient did not have access to adequate intervention at the time of the accident, which resulted in poor positioning of the orbital structures and asymmetries due to the accompaniment of the soft tissues to the bone defects caused by the trauma. The importance of an early surgical approach in these cases is highlighted, avoiding sequelae and favoring an adequate restoration of this region.

The use of osteotomies followed by bone repositioning, associated or not with grafts, represent safe surgical techniques and with good results for the correction of traumatic sequelae of the middle third of the face (Gasparini et al., 2010). The results obtained in the present case emphasize the importance of these techniques for achieving a satisfactory aesthetic resolution. When applicable, autogenous bone grafts are considered the gold standard for cranial reconstructions, however the bioavailability of this type of graft can be an obstacle for major reconstructions, as reported in this case (Da Silva et al., 2017). In addition, a study shows that there is no statistical difference related to the complication rate between the use of autogenous grafts and implants in PMMA, even though this is acrilized during the surgical procedure (Vince et al., 2019).

Case reports similar to the one presented show that manual graft customization techniques on stereolithographic models can be applied appropriately. In addition, they emphasize that the pre-surgical procedure reduces tissue damage caused by the release of the monomer after the graft is used (Ghosh et al., 2017). However, digital techniques have advanced and allow greater precision of the surgical procedure through the preparation of guides for osteotomies and for the repositioning of bone structures. In addition to reducing surgical time, digital software allows mirroring of contralateral structures or personalized reconstructions in a virtual environment. The object created for reconstruction can be made (printed or milled) in the grafting material or a negative impression can be used as a template for using the PMMA (Da Silva et al., 2017; Đurić et al., 2019). Inclusion of technologies for planning and making facial skull reconstructions, as observed in the present case, is a reality and should, in the authors' view, be encouraged to optimize clinical results. The technique used was easy to perform, relatively low cost of both hospital, planning and execution, low risk, and the result contemplate the patient's demand.

\section{Final Considerations}

We could observe that it is essential that the orbital architecture and the positioning of the adjacent bone structures are adequate for the ocular rehabilitation to have a good aesthetic result. To achieve these results, in this case osteotomy, repositioning and grafting techniques with autogenous bone and alloplastic materials were employed. The reconstruction of cranial facial structures added to ocular rehabilitation were fundamental for the improvement of the patient's self-esteem and social life.

The reported case demonstrates the applicability of conventional and digital planning for post-traumatic reconstructions, enabling ocular rehabilitation. It is expected that the present work will support future conducts of similar cases and that studies will be carried out to establish which techniques present the best clinical results for the planning and execution of complex post-traumatic reconstructions.

\section{References}

Ali, U., Karim, K. J. B. A., Buang, N. A. (2015). A Review of the Properties and Applications of Poly (Methyl Methacrylate) (PMMA). Polymer Reviews, 55(4), 678-705. https://doi.org/10.1080/15583724.2015.1031377 
Batista, T. R. M., Frazão, K. L. R., De Araújo, M. C.,De Santana Filho, E. B., Melo, A. K. V., Neves, L. E. M. (2020). Avaliação das repercussões clínicas após alterações no volume orbitário pós trauma: uma revisão sistematizada. Research, Society and Development, 9(9), 1-12. 10.33448/rsd-v9i9.7002

Cabral, L. G. M., Martelli Júnior, H., Leite, D. M., Sabatini Júnior, D., Freitas, A. B. D. A., Miranda, R. T., Swerts, M. S. O., Barros, L. M. (2008). Perfil biopsicossocial de portadores de anoftalmia no sul de Minas Gerais - Brasil. Arq Bras Oftalmol, 71(6), 855-859.

Colombo, L. R. C., Calderoni, D. R., Rosim, E. T., Passeri, L. A. (2011). Biomateriais para reconstrução da órbita: revisão da literatura. Revista Brasileira de Cirurgia Plástica, 26(2), 337-344. https://doi.org/10.1590/s1983-51752011000200025

Da Silva, R. D. P., Raposo-Amaral, C. A., Guidi, M. C., Raposo-Amaral, C. E., Buzzo, C. L. (2017). Customized acrylic implants for reconstruction of extensive skull defects: na exception approach for selected patients. Revista Do Colegio Brasileiro de Cirurgioes, 44(2), 154-162. https://doi.org/10.1590/0100-69912017002008

Đurić, K. S., Barić, H., Domazet, I., Barl, P., Njirić, N., Mrak, G. (2019). Polymethylmethacrylate cranioplasty using low-cost customised 3D printed moulds for cranial defects-a single Centre experience: technical note. British Journal of Neurosurgery, 33(4), 376-378. https://doi.org/10.1080/02688697.2019.1566514

Gasparini, G., Saponaro, G., Moro, A., Boniello, R., Cervelli, D., Pelo, S. (2010). Zygomatic sagittal split osteotomy: A novel and simple surgical technique for use in midface corrections. The Journal of Craniofacial Surgery, 21(6), 1872-1875. https://doi.org/10.1097/SCS.0b013e3181f4ab9f

Ghosh, S., Pramanick, D., Ray, A., Burman, R., Saha, A. (2017). Fronto-orbital reconstruction using polymethyl methacrylate implant. National Journal of Maxillofacial Surgery, 8, 153-156. 10.4103/njms.NJMS_10_17

Goiato, M. C., Dos Santos, D. M., Bannwart, L. C., Moreno, A., Pesqueira, A. A., Haddad, M. F., Dos Santos, E. G. (2013). Psychosocial impact on anophthalmic patients wearing ocular prosthesis. International Journal of Oral and Maxillofacial Surgery, 42, 113-119. https://doi.org/10.1016/j .ijom.2012.05.028

Gomes-Ferreira, P. H. S., Okamoto, R., De Oliveira, D., Reis, E. N. R. C., Toledo, G. L., Faverani, L. P. (2015). Tratamento cirúrgico de sequela de fratura zigomática associada à fratura maxilar complexa. Archives of Health Investigation, 4(2), 59-65.

Oliver, J. D., Banuelos, J., Abu-Ghname, A., Vyas, K. S., Sharaf, B. (2019). Alloplastic Cranioplasty Reconstruction: A Systematic Review Comparing Outcomes With Titanium Mesh, Polymethyl Methacrylate, Polyether Ether Ketone, and Norian Implants in 3591 Adult Patients. Annals of Plastic Surgery, 82( Suppl 4), S289-S294. doi: 10.1097/SAP.0000000000001801

Pine, K. R., Sloan, B. H., Jacobs, R. J. (2015). Clinical ocular prosthetics. Belim: Springer International Publishing. https://doi.org/10.1007/978-3-319-19057-

Rodrigues, M. F. B., Rocha, L. L. A., Souza, D. D., Acioly, R. F., Carvalho, D. C., Rocha, C. C. L. (2020). Tratamento tardio de fratura fronto-naso-órbitoetmoidal: Relato de caso. Brazilian Journal of Development, 6(7), 49924-49931. 10.34117/bjdv6n7-589

Rodríguez, I.Z., Aniceto, G. S., Moreno, J. J. M.(2007). Reconstrucción craneal con biomateriales. Revisión histórica y estado actual. Revista Espanola de Cirugia Oral y Maxilofacial, 29(2), 79-89. https://doi.org/10.4321/s1130-05582007000200001

Starch-Jensen, T., Linnebjerg, L. B., Jensen, J. D. (2018). Treatment of Zygomatic Complex Fractures with Surgical or Nonsurgical Intervention: A Retrospective Study. The Open Dentistry Journal, 12, 377-387. doi: 10.2174/1874210601812010377

Vince, G. H., Kraschl, J., Rauter, H., Stein, M., Grossauer, S., Uhl, E. (2019). Comparison between autologous bone grafts and acrylic (PMMA) implants - A retrospective analysis of 286 cranioplasty procedures. Journal of Clinical Neuroscience, 61, 205-209. https://doi.org/10.1016/j.jocn.2018.10.017 